\title{
Research on the properties of peat soil and foundation treatment technology
}

\author{
WANG Xingkuo ${ }^{1}$, CAO Xiuling ${ }^{1 *}$, XU Haiyan ${ }^{2}$, ZHANG Siru ${ }^{1}$, GAO Yunsheng ${ }^{1}$, DENG Zixiong ${ }^{1}$, LI Jianming ${ }^{1}$ \\ ${ }^{1}$ Hebei GEO University, School of Urban Geology and Engingeering, Shijiazhuang,China,050031 \\ 2 China MC20 Group Corp.LTD,Shanghai, China 201900
}

\begin{abstract}
In the infrastructure construction of my country and the countries along the "Belt and Road", there are many projects involving peat soil foundation treatment, but there is a lack of in-depth research on the properties of peat soil and foundation treatment technology, and there is no complete set of relevant foundation treatment technical specification systems. However, the traditional replacement method for ground treatment characteristics cannot meet the needs of energy saving, environmental protection and green development concepts. This article adopts the method of literature research, taking Sri Lanka (CKE project) as an example to introduce the engineering foundation treatment technology of peat soil in detail, and provide a reference for the construction and treatment of peat soil foundation. How to realize the technical problem of peat soil-based treatment needs to be solved urgently, so the understanding of peat soil requirements is beneficial in the long term.
\end{abstract}

\section{Introduction}

Peat soil (a collective term for peat and peat soil) is a special soil formed by organic matter and minerals under appropriate climate and topographical conditions. The total area of peat soil in the world is as high as 4.153 million square kilometers, and the distribution of peat soil in China accounts for about $4.5 \%$ of the total land area of the world ${ }^{[1]}$; my country's peat soil is mainly distributed in Yunnan-Guizhou region, southeast coast and northeast region, and peat soil distribution area in typical countries in the world As shown in Table 1, peat soil has extremely high water content, low bearing capacity, large void ratio, low shear strength, high organic matter content, and high compressibility compared to general soft soil foundations.

Table1 . A typical distribution of the total area of the country peat

\begin{tabular}{ll}
\hline Country & Area $\left(\mathrm{km}^{2}\right)$ \\
\hline Indonesia & 170,000 \\
Finland & 100,000 \\
Sweden & 70,000 \\
China & 40,000 \\
Norway & 25,000 \\
Malaysia & 22,000 \\
Germany & 17,000 \\
Brazil,Ireland, Uganda & 16,000 \\
Poland,Falkland & 15,000 \\
Islands,Chile, Zambia & \\
\hline
\end{tabular}

Note: Mesri and Ajlouni, 2007

In addition, peat soil has the characteristics of low $\mathrm{PH}$ value and very high sensitivity. The permeability and compressibility of peat soil also show anisotropy, which is often not conducive to engineering construction.
Improper handling will cause foundation settlement hazards for buildings. Poor water permeability will affect the drainage and consolidation of soil.The specific manifestation is that the settlement of the building lasts for a long time, which will cause harm to the construction and use of the building project.

Since the formation of peat soil is affected by many factors, a single physical index cannot well reflect the properties of peat soil. Therefore, for the analysis of peat soil physical indicators, it is necessary to choose peat soil-based treatment methods.

\section{Current research status of peat soil at home and abroad}

\subsection{Physical properties of peat soil}

Projects at home and abroad for less peat, so for peat land-based processing technology research has geographical limitations, physical and mechanical properties of peat soil in different regions, microstructure, also have some differences. Sri Lanka and the United Kingdom, Canada and Hokkaido similar to peat. The physical property indicators of typical areas are summarized after investigation as shown in Table 2 .

Compared with general soft soil, peat soil has a natural void ratio of about 1 to 10 times higher. The compressibility, natural moisture content, plastic limit and liquid limit are all about ten times higher. The permeability coefficient of plateau lacustrine peat soil is between sand and ordinary clay, and the permeability can reach 100 times that of general soft clay. With the increase of organic matter content, the natural water content and

\footnotetext{
*Corresponding author's e-mail address:caoxiuling@hgu.edu.cn
} 
void ratio decrease. The investigation found that hydrogeology and topography also have a certain influence on the formation of peat soil. In the lake and marsh environment, it is easy to form a continuous large area of thick peat soil. In the delta and river facies, it is easy to form discontinuous thinner peat soil with low organic matter content. The formation of peat soil in my country's Yunnan Plateau is also affected by the vertical distribution of climate. Investigations at this stage show that the earliest international literature on peat soil began in 1972, and the earliest domestic research on peat soil began in 1993. The peat soil in Qidian area was measured and finally concluded that peat soil has strong adsorption. It is the high content of organic matter and humus that have a greater impact on the properties of peat soil, while minerals should have less impact ${ }^{[2]}$. The moisture content of peat soil area of Dianchi Lake in Kunming, void ratio, density three indicators good correlation, the correlation coefficient between the void ratio and the moisture content reaches $0.94^{[3]}$.

Studies have shown that the climate around peat soil is better, and it also has a good impact on the urban environment. Fibrous peat soil has high compressibility and water absorption; Due to the high water content of peat soil, a curing agent can be added to increase the strength of peat soil ${ }^{[4]}$. Relevant documents show that the main research on peat soil stays at the theoretical level, with insufficient practical engineering experience and few engineering cases. As a result, the research on peat soil foundation treatment has not formed a complete set of survey, design, construction, monitoring, and inspection systems.

Table 2. physical property peat (typical area)

\begin{tabular}{|c|c|c|c|c|c|c|}
\hline Geographical Location & $\begin{array}{c}\text { Organic matter } \\
\text { content }\left(\mathrm{W}_{\alpha} / \%\right. \\
)\end{array}$ & $\begin{array}{c}\text { Fiber } \\
\text { content } \\
\left.\mathrm{W}_{\beta} / \%\right)\end{array}$ & $\begin{array}{l}\text { Resolution } \\
\left(\mathrm{D}_{\mathrm{u}} / \%\right)\end{array}$ & $\begin{array}{c}\text { Natural } \\
\text { moisture } \\
\text { content }(\mathrm{W} / \% \\
)\end{array}$ & $\begin{array}{l}\text { Natural void } \\
\text { ratio }(\mathrm{e})\end{array}$ & $\begin{array}{c}\text { Natural } \\
\text { density }(\mathrm{g} / \mathrm{c} \\
\left.\mathrm{m}^{3}\right)\end{array}$ \\
\hline $\begin{array}{l}\text { Western Malaysia } \\
\text { (Tropical Peat Soil) }\end{array}$ & $88.61-99.06$ & $90.25-90.49$ & - & $414-674$ & - & - \\
\hline $\begin{array}{l}\text { Malaysia (fibrous peat } \\
\text { soil) }\end{array}$ & $70-88$ & $31-77$ & $13-63$ & - & $4.1-10.5$ & $1.4-1.6$ \\
\hline $\begin{array}{l}\text { Dianchi Lake in } \\
\text { Yunnan, China (high } \\
\text { decomposition peat) }\end{array}$ & $10-84$ & $7.7-15.8$ & $60-85$ & $60-478$ & $1.5-9.2$ & $1.3-2.7$ \\
\hline $\begin{array}{l}\text { Jilin, China (fibrous } \\
\text { peat soil) }\end{array}$ & $27.3-87.2$ & - & $45-50$ & $101.7-511.7$ & $2.2-10.8$ & $0.8-1.4$ \\
\hline $\begin{array}{l}\text { Sri Lanka (amorphous } \\
\text { fiber peat soil) }\end{array}$ & $22.7-53.8$ & $54.8-82.3$ & - & $202.1-370.1$ & $2.0-12.0$ & $1.0-1.5$ \\
\hline Japan (fiber peat soil) & $30-80$ & - & $30-60$ & $330-1200$ & $7-18$ & - \\
\hline $\begin{array}{c}\text { Canada (fibrous peat } \\
\text { soil) }\end{array}$ & $68-99$ & $60-80$ & $18-28$ & $880-1590$ & $11.6-27.5$ & $1.5-1.7$ \\
\hline
\end{tabular}

Notes: The interval value in the table is the main range of the sample value. "-" means statistical lack. Data in the table from CHINA MCC20 GROUP CORP. LTD.Project Final Report on "Deep Peat Soil Engineering Characteristics and Foundation Treatment Technology Research and Application"

\subsection{Consolidation deformation characteristics of peat soil}

Mesri et al. found that when continuous secondary compression or pre-compression approaches the critical pressure, the secondary consolidation coefficient increases with time ${ }^{[6]}$. Research by Badv et al. found that the secondary consolidation coefficient of peat soils with different organic content increases with the consolidation pressure in the range of $12.5 \sim 200 \mathrm{kPa}^{[7]}$. Peat soil has a variety of special physical properties. The secondary consolidation occupies the main aspect of consolidation deformation, accounting for $25 \%$ to $35 \%$ of the total settlement. Peat soils with different densities have different consolidation characteristics. Based on the data from the test site, the CKE project summarizes the empirical formula for the overconsolidation ratio of peat soil foundation in the static cone penetration test as follows:

$$
\begin{aligned}
& \frac{S_{u}}{\sigma_{v 0}^{\prime}}=n \cdot O C R_{m} \\
& S_{u} \text { : Undrained shear strength of peat soil }(\mathrm{KPa}) \quad \sigma_{\mathrm{v} 0}^{\prime} \text { : Effective } \\
& \text { additional stress } \mathrm{n} \text { : Coefficient } \mathrm{m} \text { : Power } \\
& \mathrm{OCR}_{\mathrm{m}} \text { : Overconsolidation ratio }
\end{aligned}
$$

\subsection{Unloading and rebound deformation of peat soil}

For soft soil foundation, the unloading rebound after excavation will cause changes in the stress field, and the soil will have a certain rebound. For soft soil foundation rebound deformation, there is a critical unloading rate. When the unloading ratio of soft soil foundation is higher than the critical unloading ratio, rebound deformation will occur. Under the condition of complete unloading, the rebound deformation of peaty soil is dozens of times that of non-organic soil. Yu Zhihua studied the relationship between unloading ratio and unloading rebound rate, and believed that the deformation of soft soil foundation after unloading is divided into three stages: instantaneous, primary and secondary rebound. 
Pre-loading 50 400 kPa Kunming lacustrine peaty soil sub-resilience coefficient $\mathrm{C}_{\mathrm{re}}$ is between $0.05 \sim 0.16$, and it increases with the increase of pre-compression load ${ }^{[8]}$.

\section{Treatment of peat soil foundation}

\subsection{Related researches on peat soil foundation treatment at home and abroad}

Zhang Wurong made relevant research on the engineering properties of Jiangsu Zhenjiang peat soil through shear test and compression test ${ }^{[9]}$. For some specific engineering examples abroad, it is recommended to adopt several stabilization and construction practices, such as preloading, vacuum preloading, sand or stone pillars, surface reinforcement, chemical stabilization, and prefabricated vertical drainage ditch to improve peat foundation. Stabilizing soil with additives is a chemical method that can be used to improve soils with weak engineering properties. From an engineering point of view, the results show that the strength of $\mathrm{MgCl}_{2}$ stabilized peat is significantly improved. From an engineering point of view, the results show that the strength of $\mathrm{MgCl}_{2}$ stabilized peat is significantly improved. In addition, microstructure studies have shown that the stabilization process has led to some changes in the mineralogy, morphology, and molecular characteristics of the selected peat ${ }^{[10]}$. Table 3 briefly introduces the application and effect of peat soil treatment technology in some areas.

\subsection{Application of Overloaded Pre-compressed Stone Pile Composite Foundation in Sri Lanka (CKE) Project}

The total area of peat soil in Sri Lanka is 250,000 square kilometers. The CKE project uses sand piles to treat the foundation. The construction sequence of nearly 2,000 kilometers across the entire line uses the interlaced jump construction sequence to enhance the compactness of the sand piles, which can also enhance the compactness of the foundation and

enhance the bearing capacity of the soil; Based on the Sri Lanka CKE project shown in Table 4 to small, including Combined overload preloading of gravel pile composite foundation, Combined Overload Preloading of Sand Pile Composite Foundation, plastic slab combined with overload preloading, and overload preloading.

Table 3. Development of peat soil-based treatment technology

\begin{tabular}{|c|c|c|c|c|}
\hline Method & Area & Project & Time & Effect \\
\hline $\begin{array}{l}\text { Vibration sinking } \\
\text { gravel pile }\end{array}$ & Song Dai in China & Mustang dam road & - & $\begin{array}{l}\text { Eliminate preloading, shorten construction peri } \\
\text { od and reduce uneven settlement. }\end{array}$ \\
\hline CFG & Kunming, Yunnan & $\begin{array}{l}\text { Nanning-Kunming } \\
\text { Railway }\end{array}$ & 1993 & $\begin{array}{l}\text { In the test section, the post-construction settle } \\
\text { ment is relatively large, and it is rarely used a } \\
\text { t present. }\end{array}$ \\
\hline $\begin{array}{l}\text { Prestressed pipe } \\
\text { pile }\end{array}$ & $\begin{array}{l}\text { Dianchi Lake, } \\
\text { Kunming, Yunnan }\end{array}$ & $\begin{array}{l}\text { A municipal road } \\
\text { projects }\end{array}$ & - & $\begin{array}{l}\text { The post-construction settlement effect is relati } \\
\text { vely good, and the cost is high. }\end{array}$ \\
\hline $\begin{array}{l}\text { Overloaded } \\
\text { Pre-compressed } \\
\text { Stone Pile }\end{array}$ & Sri Lanka & CKE & 2015 & $\begin{array}{l}\text { The subsidence reduction effect is obvious, up } \\
\text { to } 31.42 \% \text {, the replacement rate is high, and } \\
\text { it has both consolidation and strengthening eff } \\
\text { ects on peat soil. }\end{array}$ \\
\hline Timber pile & $\begin{array}{l}\text { East Sumatra, } \\
\text { Indonesia }\end{array}$ & A road project & - & Temporary use, poor effect \\
\hline $\begin{array}{l}\text { Vacuum overload } \\
\text { preload }\end{array}$ & France Lance Bass & $\begin{array}{l}\text { Test section of a } \\
\text { highway }\end{array}$ & 1994 & $\begin{array}{l}\text { Can reduce post-construction settlement and in } \\
\text { crease bearing capacity. }\end{array}$ \\
\hline
\end{tabular}

Note: "-" in the table indicates missing statistics, The information of Song Dai area comes from literature ${ }^{[1]}$. Other information provided by CHINA MCC20 GROUP CORP. LTD.

Experiments have verified the settlement control effect from large It provides a basis for comparison and selection of construction schemes. The monitoring data for more than 10 years after the completion of this project, innovatively proposed the final settlement experience correction coefficient $\mathrm{m}$ value: 1.4-2.2(Possible average value of 1.7).

Table 4. Measured replacement rate, overload ratio and compression ratio of peat soil-based composite foundation treatment with bulk material piles

\begin{tabular}{ccccc}
\hline Processing method & $\begin{array}{c}\text { Replacement } \\
\text { rate } \%\end{array}$ & $\begin{array}{c}\text { Overload } \\
\text { ratio }\end{array}$ & $\begin{array}{c}\text { Compressio Improvement degree of average secondary } \\
\text { n ratio }\end{array}$ \\
\hline $\begin{array}{c}\text { Consolidation coefficient } \mathrm{C}_{\mathrm{a}} / \% \\
\begin{array}{c}\text { composined overload preloading of gravel pile } \\
\text { compoundation }\end{array}\end{array}$ & $30-50$ & $0.4-0.5$ & $17-30$ & 54.3 \\
$\begin{array}{c}\text { Combined Overload Preloading of Sand Pile } \\
\text { Composite Foundation } \\
\text { Overload preload }\end{array}$ & $40-60$ & $0.4-0.5$ & $21-35$ & 48.5 \\
\hline
\end{tabular}

Note: The data in the table is provided by CHINA MCC20 GROUP CORP. LTD. 


\section{Prospects of peat soil treatment technology}

Elsayed et al. studied the engineering characteristics of peat soil in Cranberry Bogs, Germany, and analyzed the effect of biodegradation on the secondary consolidation coefficient of peat soil ${ }^{[12]}$. The one-dimensional consolidation creep test designed by Gui Yue et al. showed that the secondary consolidation coefficient of peat soil after the decomposition of organic matter decreased, and the longer the decomposition time, the more significant the decrease in the secondary consolidation coefficient. This technology is expected to be developed into a new eco-friendly peat soil-based treatment method. Improved peat soil is expected to become a potential application field of microbial geotechnical technology. The main reaction process of microbial peat soil treatment technology is as follows ${ }^{[13]}$ : Good ventilation: $\quad\left(\mathrm{C}_{6} \mathrm{H}_{10} \mathrm{O}_{5}\right)+\mathrm{nH}_{2} \mathrm{O}+\mathrm{O}_{2} \rightarrow$ $\mathrm{O}_{2}+\mathrm{CO}_{2}+\mathrm{H}_{2} \mathrm{O}+\mathrm{Q}$

Poor ventilation: $\quad\left(\mathrm{C}_{6} \mathrm{H}_{12} \mathrm{O}_{6}\right) \rightarrow$

$\mathrm{CH}_{3} \mathrm{CH}_{2} \mathrm{COOH}+2 \mathrm{H}_{2}+2 \mathrm{CO}_{2}+\mathrm{Q}$

\section{Conclusion}

This paper adopts the method of literature research to collect the physical properties of peat soil in typical areas. Specific analysis of peat soil consolidation deformation characteristics and unloading resilience characteristics, combined with Sri Lanka (CKE project) example project, introduced the application of overloaded pre-compressed gravel piles on peat soil foundation, and proved that gravel piles can strengthen peat soil foundation The treatment is feasible and provides a reference for the construction treatment of peat soil foundation.

\section{Acknowledgments}

This work was supported by the Hebei Province Talent Introduction Project (NO.D2018014), the Hebei Province High-level Talent Funding Project (NO.E2018050005), and the Hebei Province Innovative Talent Project (NO.D2020216). International cooperation and innovation project (NO.D20210601) support.

\section{References}

1. Mesri G, Ajlouni M. Engineering properties of fibrous peat[J]. Journal of Geotechnical And
Geoenviron Engineering, 2007, 133(7): 850-866.

2. Huang Jun, Jiang Zhongxin. Engineering Geotechnical Characteristics of Qidian Peat Soil on Nankun Railway[J]. Roadbed Engineering, 1994.

3. Zhang Fange, Yang Min, Liu Kan. Research on the correlation of physical indexes of peat soil in Dianchi Lake, Kunming[J]. Building Science, 2020, 36: Supplement

4. Jiang Zhuoyin, Xu Bin. Study on the mechanical properties of solidified peat soil[D]. Kunming University of Science and Technology:2013:64-65.

5. MESRI G, STARK T D. Secondary compression of peat with or without surcharging[J]. Journal of Geotechnical and Geoenvironmental Engineering, 1997, 123(5): 411-421.

6. BADV K, SAYADIAN T. An investigation into the geotechnical characteristics of Urmia peat[J]. Transaction of Civil Engineering, 2012, 36(C2): 167-180.

7. $\mathrm{Yu}$ Zhihua.Experimental study on rebound deformation of peaty soil under axial unloading condition[J].Hydrogeology and Engineering Geology, 2015, 42(5):107-114.

8. Zhang Wurong. Preliminary study on engineering characteristics of peat soil in Zhenjiang, Jiangsu[J]. Urban Survey, 1995: 11-13.

9. Ahmad Safuan A Rashid .Effect of magnesium chloride solution on the physico-chemical characteristics of tropical peat[J]. Environmental Earth Sciences , 2016.

10. Wang Yang, Qin Xiaqiang, Lou Jianjun, et al. Research on the physical and mechanical properties of peat soil in Sri Lanka[J]. Highway, 2020 (05): 258-264.

11. Li Bo.Evaluation of the effect of vibrating sunk pipe gravel piles in strengthening soft soil foundation[J].Science Technology and Engineering, 2010, 19-4835-04

12. ELSAYED A, PAIKOWSKY S, KURUP P. Characteristics and engineering properties of peaty soil underlying cranberry bogs[C]// Geo-Frontiers 2011: Advances in Geotechnical Engineering. ASCE, 2011: 2812-2821.

13. Gui Yue.Experimental study on improving the engineering properties of peat soil using microbial technology[J]. Chinese Journal of Geotechnical Engineering, DOI: 10.11779/CJGE202002008. 